\title{
EURASIAN ECONOMIC UNION: A REGIONAL ECONOMIC HEGEMONY INITIATIVE
}

\author{
Serdar Yilmaz \\ Muğla Sıtkı Koçman University, Turkey
}

\begin{abstract}
It can be assumed that international relations terminology has not mentioned enough about the significance of the Eurasian Economic Union in territorial as well as in economic terms during a period of growing geopolitical risks and high interdependence between the member countries and the rest. According to Kazakhstan's President Nursultan Nazarbayev, it is truly difficult for states to overcome economic, political and security issues and therefore, states need to act together against the problems in a globalizing world by establishing regional and international organisations. This article thus examines the Eurasian Economic Union integration process, which is driven by political and economic factors that consolidate regional security and create an effective economic system, whether it in the long term will become successful or not. The author also analyses the Kazakh economic and strategic interests in the region as well as the motivation, power and influence of other members in deepening the cooperation with the international arena and the limits in the economic-security integration.
\end{abstract}

Keywords: Eurasian Economic Union, Dependency, Russia, Kazakhstan, Nazarbayev.

DOI: http://dx.doi.org/10.15549/jeecar.v4i2.166

\section{INTRODUCTION}

With the accelerating pace of globalization after the Second World War, border obstacles to trade between the countries began to disappear and there have been important developments with the increase in the inflow of foreign capital. Expansion in economic cooperation after this devastating war showed progress in two main directions as international economic cooperation organizations and international economic integrations. International economic cooperation organizations have emerged for eliminating and solving the problems that may arise in the relations between member countries. Such organizations reflect the solidarity and cooperation among the countries' efforts in certain areas (Lagutina, 2013). United Nations Regional Development Banks, World Trade Organization, Organisation for Economic
Co-operation and Development (OECD) and Organization of the Petroleum Exporting Countries (OPEC) are such institutions that can be an example to them.

Another extension of economic cooperation is international economic integrations that are usually emerged on the basis of trade liberalization among the countries in the same geographical area. This type of integration brings many benefits like geographic and cultural proximity, transportation, transport and border trade. The main reasons why countries desire such an integration are: to expand the production capacity of member countries, to increase economic efficiency, to achieve greater competitiveness against outside countries or economic blocks, to take a more active role in international political struggle and to speak with one voice to eliminate the conflicts arise 
between neighboring countries. According to Sherbarova, globalisation is the main reason to explain this situation as there has been a process of moving from nation-states to regionstates (Shebarova, 2005).

\section{AIM AND HYPOTHESIS}

Although there are many economic integrations in today's world, the world economy is viewed as a three-group structure/block. The first block is the West Europe where the European Union (EU) is the centre. The second one is the North American Free Trade Agreement (NAFTA) which America is leading. The last block is the Asia-Pacific Economic Cooperation (APEC) that is composed of East and Southeast Asian countries. The other groups that are out of these blocks have limited impact in terms of trade figures in the world. On the other hand, some radical changes and uncertainties in the international system occurred with the end of the Cold War and the dissolution of the Soviet Union made some changes in the world order. Socialist regimes in the Eastern bloc collapsed swiftly in this process of change and many independent states emerged after the dissolution. The uncertainty left its place to institutional relations with the establishment of the Commonwealth of Independent States (CIS) but it was still essential to establish an international union to fill the gap in the commercial, economic, cultural and security fields that created by the Soviet Union. This situation both ensured the emergence of new economic and political opportunities and signalled that three blocks of the world economy may rise to four in Eurasia. In particular, taking the success, the depth and width of the EU into account, the Eurasian Economic Union (EAEU) stands as an important organization which is believed to increase activity in the future as the foundations laid in 1994 in Asia and began to base its institutional identity since the beginning of the 2000s.

This article thus aims to examine the EAEU integration process which contains political and economic factors that consolidate regional security and create an effective economic system. The study also analyses the Kazakh economic, security and strategic interests in the region as well as Kazakh President Nursultan Nazarbayev's motivation, power and influence of other members in deepening the cooperation with the international arena and the limits in the economic-security integration. Therefore, the hypothesis of the study is as follow: The EAEU will be a successful economic integration model in the long future if only the member states continue to act with the purpose of having the Union stay as an economic integration model.

\section{CONTENT}

The study will base the terms of the success of the EAEU integration on possessing certain requirements such as similarity in economic structure, infrastructure facilities, investment policies, geographical proximity and political and cultural closeness. For instance, the first of the requirements for an economic integration to be successful is a similarity in economic structure. As Güran and Aktürk (1997) discuss that underdeveloped countries' industries cannot compete in a free trade environment against industry of developed countries. People in less developed countries who have insufficient skilled labour and capital might move to a developed one and therefore, an integration that is established between the countries who have similar economic structures can become more successful. The second requirement is the infrastructure facilities. For example, a reciprocal trade will be easier in countries involved in the integration as developed infrastructure facilities provide production efficiency and manufacturing of high value-added products. Yiğit (2003) points out that while developed infrastructure facilities like rail, air, industry and energy increase the success of the integration, inadequate infrastructure facilities reduce the success of it.

Because the investment for developing countries is of great significance, the third requirement necessary for the success of economic integration is investment policies. An economic integration which will be built in an area that attracts foreign and local investment is likely to be successful. According to Sabir (2002), if countries prefer maintaining their investment policies through integrated central agencies or with the coordination of their national organizations they will also provide efficiency and productivity the resource allocation. Thus, the similar investment policies between members of an integration increase the success of the integration whereas different investment policies of integration reduce the chances of its success. As for finding solutions 
together to common problems and evaluating joint opportunities, it is a right attitude for the countries in the same region to take part in the integration movement. Therefore, the fourth condition necessary for the success of economic integration is geographical proximity. Especially in the last 20 years despite the rapid development in technology, transportation and communication field, both the transport costs between countries who are far away from each other and time-consuming transportation have hampered the development of economic relations. Therefore, the geographical proximity of the countries in international economic integration is emerging as one of the major requirements (Güran and Aktürk, 1997).

The fifth requirement which is necessary for the success of economic integration is political and cultural closeness. Socio-cultural closeness among the member countries of an integration is related to factors such as common language, cultural characteristics, similar types of education, a way of life, business and industrial practices. One of the main determinants of international relations discipline is to be aware of the communities that belong to different cultures around the World (Kargül, 2010). Because of functional integration and effective coordination between the members' societies can be prepared for the applicability and acceptance of the decisions taken. Political and cultural closeness make people better understand and better communicate (Çak and Çak, 2007).

Mircan (1999) argues that the concept of integration can occur in three different ways in the literature. First, national integrations that aim to integrate each of the different regions within a country's borders, second, international economic integrations that aim to integrate different countries within a region and lastly the global integrations that refer to integrate the different regional groups in order to become an effective single economic and political unit. The EAEU, as it can be seen from this definition, is an example of international economic integration that aims to integrate different countries within a region.

Balassa (1961) seems to accept that there are different sizes and different stages of economic integrations as he explained the phases of economic integrations as Trading Agreements, Free Trade Association, Customs Union, Common Market and the Economic Union. It will be seen in the next part that the EAEU has experienced such phases since its first appearance. According to İncekara (1995), countries who desire to be a part of an integration aim to take advantage of the benefits and maximize the common interests of the countries that joined the integration. Thus, the success of integration is dependant on the short and long term expectations of countries who wish to reach their target. Although there is not a common prescription leading an economic integration to success, empirical studies in the literature demonstrate that the success or failure of economic integrations in the long term depends on meeting some requirements/conditions.

\section{EURASIAN ECONOMIC UNION}

The world system has witnessed three main economic blocs (structure) since the Second World War, but the recent history of attempts to reintegrate the post-Soviet land has been littered with ineffective economic and political initiatives. The only fruitful economic project established by Russia, Kazakhstan and Belarus was the Customs Union which became the Eurasian Economic Union in May 2014 (implemented in January 2015). In fact, there are two Eurasian Unions. One of them is real and already exists, called the Eurasian Economic Union and the other one is rather imaginary called the geopolitical Eurasian Union. The real EAEU is a respected international organisation which has a headquarter, an institutional identity, bureaucrats and professional employees. Member states exchange capital, labour and goods among themselves (Popescu, 2014). This real EAEU is based upon the President of Kazakhstan Nursultan Nazarbayev's understanding of Eurasianism. He sees the Union as just an economic integration which ensures to be the provider of regional economic welfare and regional security. Thus, Nazarbayev (2014) put forward the aim of the EAEU as follow: "The aim of the EEU is not to create barriers against the rest of the world, but to improve our cooperation with other member states. Kazakhstan, Belarus, and Russia create the Union in a spirit of strategic partnership and friendship. The economic integration will considerably increase economic capabilities of all countries."

However, as for the other Eurasian Union fuelled by geopolitical desires, Russian President 
Vladimir Putin embraced the Union as the key foreign policy objective (Putin, 2011). According to Popescu (2014), Putin sees the Eurasian Union as not only a new round of post-Soviet reintegration, but also he wishes to turn it into a distinctive block of influence like the EU, NAFTA and APEC. Popescu (2014) continues to argue that "instead of smoothing the path towards post-Soviet reintegration, Russia finds that it has painted itself into a geopolitical corner, where no post-Soviet states want to join. Against this backdrop, Putin's dream of a Eurasian Union that will evolve into a powerful geopolitical bloc seems much less likely to materialise." So, this paper also argues whether the EAEU is a new version of the Soviet Union of the twenty-first century or if it is just a regional economic body which has a potential as Nazarbayev perceives.

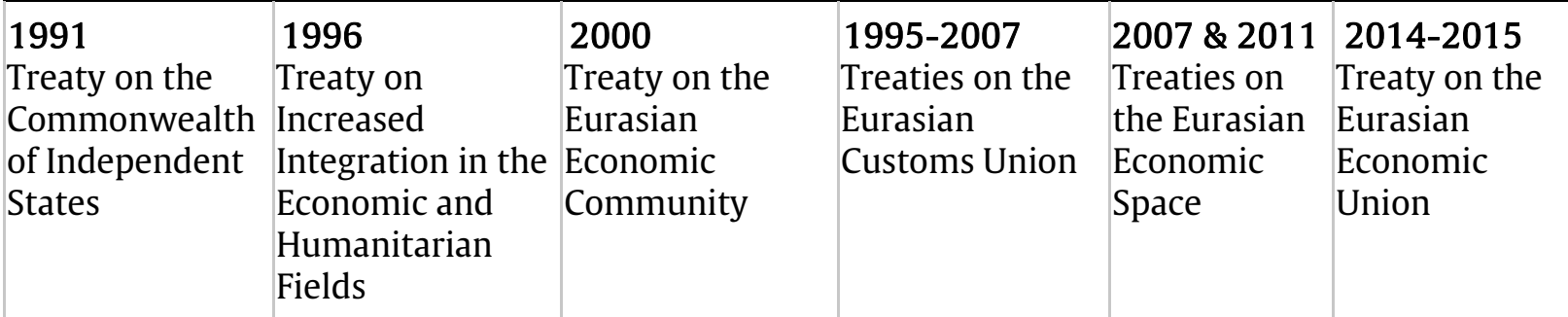

Table 1. Structural Process of the Eurasian Economic Union

Source. "Eurasian Economic Integration: facts and figures", Eurasian Economic Commission, 2015, pp. 6-9. http://www.eurasiancommission.org/en/Documents/broshura26_ENGL_2014.pdf, (formed by the author).

\begin{tabular}{|l|l|l|}
\hline Country & Signature Date & Accession Date \\
\hline Russia & 29 May 2014 & 1 January 2015 \\
\hline Kazakhstan & 29 May 2014 & 1 January 2015 \\
\hline Belarus & 29 May 2014 & 1 January 2015 \\
\hline Armenia & 10 October 2014 & 2 January 2015 \\
\hline Kyrgyzstan & 23 December 2014 & 12 August 2015 \\
\hline
\end{tabular}

Table 2. The Member States of the Eurasian Economic Union

Source. "Eurasian Economic Integration: facts and figures", Eurasian Economic Commission, 2015, pp. 6-9. http://www.eurasiancommission.org/en/Documents/broshura26_ENGL_2014.pdf, (formed by the author).

The idea of Eurasian integration project turned 22 years since its first inauguration by Nazarbayev at Moscow State University in 1994. He proposed to develop a functional union of the states on the grounds of the interconnected economies. Unlike the Commonwealth of Independent States (CIS), the Eurasian Union was supposed to have a full-fledged institutional structure and possess a sufficient scope in the key sectors of the economy. According to Kassenova (2012), at the time Moscow was not ready for this initiative as she was reviewing her foreign policy, however, in August 1994, a statement saying that Moscow was ready to go in the integration with CIS countries was made by Russian Foreign Minister Andrey Kozyrev. In the beginning of 1995, Kazakhstan, Belarus and Russia signed an agreement about the Customs Union proposed to remove the barriers for free business cooperation and ensure the free exchange of goods and fair competition. In 1996, the heads of three countries and the President of Kyrgyzstan signed a treaty on expanding the 
integration in economic and humanitarian fields which reflected the close economic and cultural ties. Determination of moving to a closer mutual work based on standardising the laws and structural reconstruction of economies resulted in a new integration structure namely the Eurasian Economic Community (EurAsEC) in 2000 (Mostafa and Mahmood, 2013).

Since 2003, leaders have been boosting the legal framework for the Common Economic Space. In October 2007, a Treaty on establishing the common customs territory and forming the Customs Union was signed between Belarus, Kazakhstan and Russia and began its work in January 2010. Today, the rules of the Common Customs Code and the Common Customs Tariffs are applicable on this territory (Eurasian Economic Commission, 2015). Wisniewska (2012) argues that the aim of this regulation is to set uniform principles for the member states related to export, import and transit of goods. On November 18, 2011, the Presidents Alexander Lukashenko, Nursultan Nazarbayev and Vladimir Putin signed a declaration on Eurasian Economic Integration. With this document, the leaders acknowledged the Customs Union to be a success and expressed their enthusiasm in further integration. The declaration demonstrated the move towards the next stage of the integrative construction namely a Single Economic Space (SES).

By January 1, 2012, a legal framework of the SES which assumed as a market with 180 million consumers, the unified legislation, free movement of goods, services, capital and labour, was formed. According to Vinokurov (2012), "SES will increase competition and create equal conditions for all businesses and investors and will eliminate the structures of national legislation at every stage of the business transaction and guarantees an overhaul of technical regulations and standards." The SES is founded on the key sectors of economic regulation, competitive sphere, industry, agriculture and transport. On February 2, 2012, a supranational permanent executive body called the Eurasian Economic Commission (EEC) began its work. The main objective of the EEC is to ensure the functioning and development of the EAEU, and build up proposals for the further process of integration (Eurasian Economic Commission, 2016). The year 2013 included the work to ensure that Kyrgyzstan joined the Eurasian integration project as was initially adopted in 2011. In May 2013, a memorandum on extending the scope of mutual work between Eurasian Economic Commission and Kyrgyzstan was signed. On September 3, 2013, Armenian President Serzh Sargsyan announced the intention of his country to join the CU and CES and in the construction of the EAEU. On October 24, 2013, at the session of the Supreme Eurasian Economic Council, the Presidents of the Member States accepted the Armenian application and instructed the EEC to launch the work on accession (Eurasian Economic Commission, 2015).

In 2013-2014 the Eurasian Economic Commission and the authorities of the founding countries prepared the treaty on the Eurasian Economic Union (EAEU). On May 29, 2014, during the session of the Supreme Eurasian Economic Council, Lukashenko, Nazarbayev and Putin signed the treaty on the establishment of the Eurasian Economic Union. On October 10th, 2014, an Agreement of Accession of Armenia to the EAEU was signed in Minsk. On December 23, 2014, in Moscow, Kyrgyz President Almazbek Atambayev signed the treaty on the accession of Kyrgyzstan to the EAEU. On August 12, 2015, after implementation of the "roadmap" and completion of ratification procedures, Kyrgyzstan became a full-fledged member of the EAEU (Ministry of Foreign Affairs of Republic of Belarus, 2016).

It is a symbolic coincidence that Nursultan Nazarbayev redelivered a speech regarding the Eurasian Union at Moscow State University on April 2014. Unlike the lecture Nazarbayev delivered 20 years ago which Russia was not interested in, this time the world witnessed how his proposal received such significant practical implementation gradually over the years. He also demonstrated his faith in successfully sustaining the Union for years. The President of Kazakhstan stated: "The strategy of the Eurasian Economic Union is based on the truth similarly close and clear to any citizen of our countries. The common history, the mutual economic attraction, the close interconnection of the cultures and proximity of the human aspirations give our nations a chance to build a new type of multilateral interstate connections." (Eurasian Economic Commission, 2015).

\section{THE EFFECTIVENESS OF THE EURASIAN ECONOMIC UNION IN THE REGION}

The Eurasian Economic Union has international legal personality and is the 
established by the Treaty on the Eurasian Economic Union. Although it's a union founded considering the EU treaty as an example, political integration isn't among its goals. As it was stated before, one of the most significant goals of the EAEU is to become one of the greatest commercial blocs of the world. After almost two years of existence, it can now be drawn preliminary conclusions about the EAEU's results and check it against the initial aims stated above. The range of scientific studies regarding the gains, losses and implications of members' participation in the project remains broad and polarized. However, the EAEU looks a potential candidate to be the fourth economic block in the world by looking its percentages. For example, population of the

\section{Graph 1. Oil and Gas Extraction of the EAEU Oil Extraction}

I place in the world- $14.6 \%$ of the global share Total in CU and CES

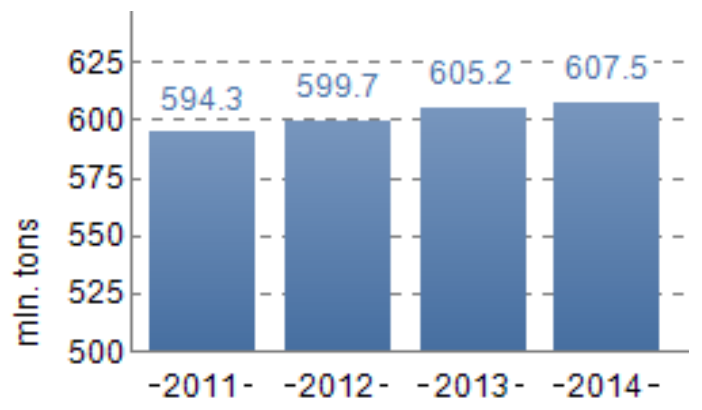

EAEU as of January 1, 2016, was 182.7 million people (2,5\% of the world population), gross domestic product of the EAEU in 2014 was $\$ 2.2$ trillion dollars (3,2\% of the world GDP), industrial production in 2014 was 1.3 trillion dollars $(3,7 \%$ of the global industrial production), volume of external trade of the EAEU with third countries in 2014 was 877.6 billion dollars (3.7\% of the world export and $2.3 \%$ of the world import), oil production is 607.5 million tons ( $1^{\text {st }}$ in the world - $14,6 \%$ of the global production) and gas production is about 682.6 billion cubic meters $\left(2^{\text {nd }}\right.$ in the world $18,4 \%$ of the global production) (Eurasian Economic Union, 2016).

\section{Gas Production}

II place in the world-18.4\% of the global share Total in CU and CES

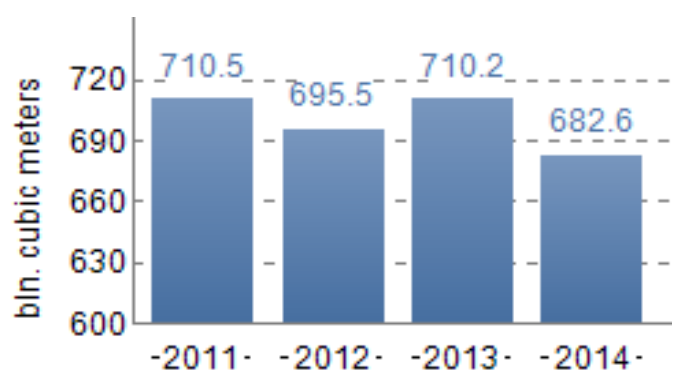

Source. http://www.eurasiancommission.org/en/Pages/ses.aspx

To begin with, official sources report rather positive trends in Customs Union trade. According to the statistics published by the Eurasian Economic Commission (2011), mutual trade volumes within the Customs Union grew on a year-on-year basis by $29 \%$ in $2010,34.6 \%$ in 2011 and 13.5\% in the first half of 2012, thus underpinning a rather strong trend of intrabloc trade increase over a 2.5 year period. However, after initial growth in the first two quarters of 2010, Russia's exports to the EurAsEC remained highly stable for a year. The export volumes picked up substantially in 2011 only to decline in the first half of 2012. According to Blockmans, Kostanyan and Vorobiov (2012), "this development leads us to assume that Russia's export of ferrous metals could have been initially encouraged by the improvement of trade conditions within the $\mathrm{CU}$, yet failed to have a sustainable effect, with Russia's exports to its member countries returning to the pre2010 levels in mid-2012." Anders Aslund (2016) puts forward that although Russia declared the EAEU as a free trade area, this organisation does not seem to benefit Russian's interests as plenty of agriculture goods are blocked from entry into Russia due to Russian sanitary regulations. Thus, Russian consumers do not benefit from cheaper food.

As for Armenia, prices of imported goods jumped because her import tariffs were lower than the tariffs Russia imposed on the EEU. When Armenian President Serj Sarkisyan signed the membership agreement into the EAEU, he thought to benefit more from this membership. Hewever both the economic recession in Armenia and the devaluation of Russian Ruble, Armenians goods have been ceased to be profitable to sell and therefore, the export rates 
are declining. For example, in the first half of 2015, the Armenian export to Russia declined by 47 percent (Sahakyan, 2016). Ryhor Astapenia argues that especially the first year of the EAEU has highlighted how differently Russia and Belarus perceive the EAEU which brought poor economic results for Belarus in the first year. In the first six months of 2015, the trade between Belarus and other EAEU members was \$2.5 billion less than in the first half of 2014. As a result of the reduction of a large number of trade tariff exemptions, Belarus' trade within members of the EAEU fell by a third. As a result according to Astapenia (2015), editor-in-chief of Belarusian internet magazine Idea, "the economic decline, particularly in Russia, undermines incentives of countries to integrate further. Under such conditions, the first year of Belarus membership in the Eurasian Economic Union has shown rather poor results. Eurasian integration remains more about hype than substance."

\begin{tabular}{|l|c|c|}
\hline Members & $\begin{array}{c}\text { January- } \\
\text { June (2014) }\end{array}$ & $\begin{array}{c}\text { January- } \\
\text { June (2015) }\end{array}$ \\
\hline Russia & $18,345,20$ & $14,417,60$ \\
\hline Kazakhstan & $7,991,20$ & $5,312,80$ \\
\hline Belarus & $3,540,80$ & $2,674,30$ \\
\hline Kyrgyzstan & 226,5 & 162,9 \\
\hline Armenia & 141,1 & 92,9 \\
\hline
\end{tabular}

Table 3. Trade Between EAEU Member States $(\mathrm{m} \ln \$)$

Source. http://belarusdigest.com/story/belarusand-declining-eurasian-economic-union-23846

As it was stated before that Kyrgyzstan completed its accession to the EAEU in August 2015 and the result of this membership is a bit mixed so far. One of the major reasons to join the Union was both gaining access to markets and Kyrgyzstan's large population of migrant workers in Russia where over half a million Kyrgyz are presently working and sending remittances (Putz, 2016). Kyrgyzstan's trade with the other members has been decreased from 226,5 million in January-June 2014 to 162,9 million in January-June 2015. The deflation of the Russian Ruble also reduces exports and the value of the Kyrgyz Som which lost about 30 percent of its value against the U.S. dollar in 2015. Due to the weak valuation of Ruble, Kyrgyz remittances fell from about \$2.06 billion in 2014 to $\$ 1.38$ billion in 2015. A year after Kyrgyzstan's accession to the EAEU, Galdini and Nematov put forward that "the EAEU common tariff system which is based on Russia's higher tariffs has translated into a sharp increase in prices for imports coming from nonEAEU members such as China and Turkey." When Kazakhstan rushed in new rules for the import of cars from Kyrgyzstan, they embarked on wondering about the actual meaning of "free trade" within the bloc (Galdini and Nematov, 2016).

The idea of Eurasian integration has always been hard to embrace after the dissolution of Soviet Union, however, Kazakhstan President Nursultan Nazarbayev has been the most persistent and faithful promoter of this idea as support and enthusiasm to it varies by country to country. Nazarbayev described and based the principles of his vision of the Eurasian Union in an article in the Russian Newspaper Izvestia (October 25, 2011) on four principles:

- The integration must be built on economic pragmatism.

- Member countries must decide independently whether they want to stay within their own boundaries or join the globalized world.

- Principles of equality, mutual respect for sovereignty and non-interference in domestic affairs of others must be respected.

- Member states should create their national institutions on the principles of consensus of all participants without giving up national sovereignty (Nazarbayev, 2011).

Nazarbayev (2013) also refuses the criticism of too much leaning on Russia by stating "we are not pro-Russian, pro-Chinese, pro-European, or pro-American in our foreign policy. We are proKazakh, if Russia can help us, we will turn to Moscow, but if Russia cannot offer us what we need to pursue our interests, we will turn elsewhere. It is simply pragmatic." Mostafa (2013) argues that "Kazakhstan's Eurasian policy is designed to improve relations with Russia and other regional countries based on Eurasian solidarity, playing the role of a 'bridge 
between Asia and Europe' and claiming as a bastion of peace, stability and neutrality." However, it can be argued that Russia has a more competitive economy together with immense reserve of natural sources and thus any common tariff policy might benefit only Russia rather than Kazakhstan. In that case, it is meaningful to ask whether Kazakhstan has benefited economically from the EAEU or not.

In 2010, the total trade between Kazakhstan and Russia raised from $\$ 12.4$ billion to $\$ 17.9$ billion and in 2011 the total trade amount increased to $\$ 22.7$ billion. While the total share of export to Russia and Belarus was $10.1 \%$ in 2010 and $8.5 \%$ in 2011, Russian share of import to Kazakhstan increased from 31.3\% in 2009 to 41.4\% in 2011 (Statistical Agency of the Republic of Kazakhstan, 2011). After the membership to the Customs Unions, tariffs on equipment increased by $10-20 \%$ and previously imported with zero tariff materials raised by $20 \%$. Thus, Kazakh producers using Western equipment and materials were badly affected. According to Kassenova (2012), higher tariffs protect Russian producers as Russian goods have full access to the Kazakh market whilst some Kazakh goods have been blocked with the help of non-tariff barriers. There is a fear that Russian companies might dominate the Kazakhstani market and reshape it accordingly as the number of Russian companies increasing every year. Unlike what some critics think, Kazakhstan's ruling Nur Otan party support further economic integration and strengthening the country's national interests in the EAEU (TASS, 2016).

Kazakhstan's overall external trade turnover fell by 29 percent within the EAEU and by 37 percent in the year of 2015. The Kazakh national currency, the tenge, has lost half its value against the dollar since last August 2015. The problem of devaluation of members' currencies -under the pressure of falling oil prices and Russia's soaring economy seems to be a worrying matter that members spent an average of $10-15$ percent of their sovereign reserves to defend their national currencies that are wilting (EurasiaNet, 2016). Kazakhstan has not gained enough through the EAEU as Nazarbayev complained in October 2013. He complained that the Customs Union imposed more costs than benefits for Kazakhstan. While her exports to Russia and Belarus fell by $4 \%$ approximately 7 billion dollars, her imports increased by 17 billion dollars in reverse. According to Nazarbayev, in his speech in gazeta.ru, he was also complaining about the problem with free access to Russian electricity market and obstacles for exports of Kazakh meat products (Gazeta.ru, 2013).

\begin{tabular}{|l|l|l|l|l|}
\hline Members & $\begin{array}{l}\text { GDP in } \\
2014 \\
\text { (billion } \\
\text { US\$) }\end{array}$ & $\begin{array}{l}\text { Country's GDP } \\
\text { share in the GDP } \\
\text { of the entire EAEU } \\
(2014)\end{array}$ & $\begin{array}{l}\text { Trade with EAEU } \\
\text { countries during } \\
\text { January-November } \\
\text { 2015 (million US\$) }\end{array}$ & $\begin{array}{l}\text { Share of trade with } \\
\text { Russia in trade with } \\
\text { EAEU countries during } \\
\text { January-November 2015 }\end{array}$ \\
\hline Kazakhstan & 212.2 & $9.7 \%$ & 15212.9 & $91.9 \%$ \\
\hline Kyrgyzstan & 7.4 & $0.3 \%$ & 2058.8 & $63.9 \%$ \\
\hline Russia & 1880.60 & $86.0 \%$ & 40300.7 & $96.9 \%$ \\
\hline Armenia & 10.9 & $0.5 \%$ & 1179 & $97.4 \%$ \\
\hline Belarus & 75.9 & $3.5 \%$ & 24503.8 & \\
\hline Total & 2187 & $100 \%$ & & \\
\hline
\end{tabular}

Table 4. The GDP of the EAEU members (2014) and their trade within the EAEU (January-November 2015)

Source. the Eurasian Economic Commission, http://www.eurasiancommission.org

\section{NAZARBAYEV'S EURASIANISM AND THE EAEU}

The EAEU initiative supported by especially Nazarbayev can be assessed within the context of the Eurasianism. According to Michael Alexandrov (1999), the idea of Nazarbayev's Eurasianism is based on the continuation and development of the ties with both Russia and 
the neighbouring countries and if possible, the establishment of a union since the dissolution of the Soviet Union. Nazarbayev put forward the establishment of the EAEU for the first time in 1994 and defended the formation of a strictly financial and economic integration with the former Soviet countries. In 1992, he put forward such proposals as the acceptance of the Russian currency Ruble as a supranational currency even before the Turkish (Turkic) republics established their own national currency system, the creation of the economic rules and banking union of the CIS and the strengthening and functionality of the defence alliance.

The need to revise CIS in a structural level has been expressed many times by Nazarbayev in time. For example, in a speech Nazarbayev made at the London's Chatham House on 22 March 1994, he mentioned a formation that would have rules like those of the European Union and that would be joined by the countries complying with these rules (Imanov, 2007). In another speech he delivered at the Moscow State University on 3 June 1994, Nazarbayev brought the Eurasian Union project in a more concrete and detailed way. He planned to unite CIS countries within a more functional, dynamic and small integration model and thus, based the integration on a solid foundation. This idea was accepted by Russia's science and business circles but was approached with vigilance by the Kremlin. In the conclusions of the scientific conference organized under the titles "Eurasia Cooperation Opportunities" in Almaty on September 1994, a decision was made to take a step towards improving cooperation opportunities by making use of the states' idea of the Eurasian Union and other cooperation projects (Nazarbayev, 1997).

In the following period, with Vladimir Putin's coming to office, Nazarbayev's idea of the gradual integration was supported by Russia as they established the Eurasian Economic Community (EEC) in the early 2000s. It must be noted that Nursultan Nazarbayev personally bases the Eurasianism and the resulting idea of Eurasian Union on this following ground: "first of all, in order to ensure economic integration, there must be a pragmatic integration process proceeding gradually and at different speeds and that will ensure security in an overall approach, not at individual level and thus, the search for a regional security mechanism." (Nazarbayev, 2004). However, this situation has brought about some criticism and some saw the
Eurasian integration as the revival of the Soviet Union. In a speech in 2011, Nazarbayev (2011) said: "These were being mentioned in the past; there were speculations and some people had dreams on this issue. However, today just like Lukanşenko and Putin, I do not have such ideas. Nobody mentions NAFTA including the USA, Canada and Mexico and criticizes their search for a union. Nobody looks for imperialistic ambitions there. Why not carry out the same with Eurasia."

Since 1 January 2012, the Union has become a legally single economic space and it came into force as the Eurasian Economic Union as of May 2014. In the summit organized in the capital of Belarus, Minsk, on 10 October 2014, Armenian President Serj Sarkisyan signed the membership agreement into the EEU and the number of members increased to four. The number of members increased to 5 with the membership of Kyrgyzstan in August 2015. From time to time, rumours are circulating that Turkey may also join the Union. Especially Nazarbayev has belief that with the membership of Turkey as he perceives Turkey as a part of his understanding of Eurasianism, the membership process of both the Black Sea countries and the other Turkish states will gain momentum. Thus, in the event of Turkey's membership, the message that the objective of the Eurasian Union is not the creation of the USSR will be given. For example, Nazarbayev gave the following message to those who regard the EAEU as an initiative to revive the USSR and clarified his position to Turkey: "They say we are establishing the Soviet Union. This problem will automatically vanish with the membership of Turkey." Therefore, Turkey's membership in the Union has a potential to accelerate all these processes and Nazarbayev is aware of Turkey's potential Mominkılov, 2012).

For Nazarbayev, the EAEU is an economic goal as it was previously specified. However, it can be argued that Russia wants to integrate with the EAEU in the region and maintain the influence she had in the past. Therefore, Russia views the project as being a blocking or balancing factor against the Euro-Atlantic block and the unipolar world vision imposed by the USA. This does not mean that the EAEU is a long-term and one hundred percent integration based on the economy. However, this study does not agree with the allegation that Russia plans to establish the new Soviet Union contrary to what some allege. This matter definitely has a political aspect. Seeing that the Western 
countries led by the USA and the EU try to spread their values to the international arena, Russia thinks that she needs to preserve her domain she had in the past. Therefore, Russia tries to be one of the determining actors of the international arena by creating a regional integration (Özdal, 2015). That's to say, those countries that gained independence with the dissolution of Soviet Union and are now members of the EAEU made great effort to consolidate their independence and improve their economies for such a long period of time. It is not expected to turn this integration into a political structure as both Russia and other countries learned their lessons from history.

\section{THE EAEU ADMINISTRATION BODIES}

The Eurasian Economic Union can be summarized as to protect the economic interests of its members in particular. Although the last year, Kazakhstan has given clear examples of anxiety over Russia's bid to introduce European Union-like institutions into the Eurasian space the signing of Treaty on the Eurasian Economic Union on May 29, 2014, in Astana laid down the structure of permanent institutions of the EAEU (EurasiaNet, 2016). The main body of the Union is the Supreme Eurasian Economic Council (SEEC) which is a supreme body and consists of member-states' Presidents (MFA of Republic of Belarus, 2015). SEEC sessions are held at least once a year. It is the decision making the body as it determines the strategy, instructions, ways and prospects for the formation and development of the EAEU (Eurasian Economic Commission, 2015). The SEEC also approves the budget and the distribution of the contribution of the member states of the EAEU (Eurasian Economic Union Law Portal, 2014).

Another administration body of the EAEU is the Eurasian Intergovernmental Council (EIC), which consists of the Heads of the memberstates' Governments who meet twice a year to discuss both whatever proposed by the SEEC and issues for which no consensus was reached during decision-making session. Decisions, orders and recommendations of SEEC and EIC are taken by consensus (Belarus' Presidency in the EAEU bodies, 2015). One of the most important institutions of the EAEU is The Eurasian Economic Commission (EEC) which is a permanent supranational regulating body of the Union that consists of the Council of the
Commission and the Board of the Commission (Eurasian Economic Commission, 2015). The Eurasian Commission was modelled on the European Commission (BBC News, 2011). Its headquarters are in Moscow. The main tasks of the Commission are to enable the functioning and development and to develop proposals in the sphere of economic integration within the Union. The EEC can take decisions regarding the customs policy of the union as well as about the macro-economy, the competition regulations, the energy policy and the fiscal policy of the EAEU. The EEC is a permanent regulating body of the EAEU and within its powers, it adopts decisions with regulatory and binding effect for the Member States, organisational and administrative orders and non-binding recommendations. Decisions of the Commission form part of the Union law and are directly applicable to the territories of the member states. The decisions, orders and recommendations of the Board of the Commission are taken by the qualified majority (Belarus' Presidency in the EAEU bodies, 2015).

The last institutional body of the EAEU is the judicial branch represented by the Court of the Union. The judicial body of the EAEU aims to "ensure the uniform application by the Member States of international treaties in the framework of agreements concluded with third parties." (Eurasian Economic Commission, 2015). It is in charge of dispute resolution and the interpretation of the legal order within the EAEU. Its headquarters is in Minsk (Borovikov and Danilov, 2014). The Court protects the interests of third state producers and investors and composed of two judges from each member state, appointed by the heads of government of the member states (Eurasian Economic Union Law Portal, 2014).

\section{DISCUSSION}

This study asserts the EAEU as a potential international economic block established to streamline the flow of goods, labour and capital among its members. In order to secure a proper place in the three structures of the world economic system, the EAEU members develop their project of economic integration as the Union has a potential for expansion as the fact that it is being monitored on a global scale. For example, in February 2016, Moscow hosted a meeting between representatives of the EAEU and experts of the World Bank to discuss the 
cooperation in the field of tax policy within the Union (Eurasian Economic Commission, 2016). In January 2016, not only Iran but also Israel declared that they were quite confident to remove the barriers and reach free trade zone (Sputnik, 2016). With the announcement of Kazakhstan, the EAEU and Shangai Cooperation Organization (SCO) are on the verge of an idea to create an SCO free trade zone which is called Economic Continental Partnership (TASS, 2016). As Andrey Slepnev, the EAEU trade minister, said earlier in 2016, the Union has a solution with Egypt as well on the subject of free trade zone and experts will complete the infrastructure next year to move to the negotiations stage (TASS, 2016). The EAEU is also supporting China's initiative of the Silk Road Economic Belt to create an economic partnership and Russian President Putin is quite keen to finalise it (TASS, 2015).

On the one hand, interaction with third countries, international organizations and integration associations allow the EAEU to expand its horizon and the interests of the members as the Union is becoming the centre of attention. It encourages regional economic integration and thus, many countries like Pakistan, Serbia, Thailand, Indonesia, Cambodia and India have expressed interest in order to create a free trade zone within the bloc (Libertas, 2016). On the other hand, the creation of the EAEU coincided with a severe economic recession in the Russian economy. Over the Ukrainian crisis with Russia, the sanctions imposed by Western countries against Moscow had also negative effects on the economies of other member countries. It can not be denied to point out that oil is a major source of income in the Russian and Kazakh economies. However, the fall in oil prices has slowed Kazakhstan's Gross National Product growth. On the other hand, with the rapid devaluation of Ruble currency, prices of Russian goods have become cheaper and thus the competitiveness of the goods produced in other countries of the EAEU, primarily Kazakhstan, weakened accordingly.

Although all the EAEU members have relatively a large domestic market, like in any economic union, the winner is always the country where the economy is more developed. Thus Russia has the potential to help solve the Union's interregional problems as Moscow plays a constructive role as a "solicitor" between EAEU member countries. For Minsk, the EAEU means access for Belarusian goods to the
Russian market, other members and potential members of the Union. The study demonstrated that the EAEU can facilitate economic interactions. Minsk's motive for integration with the EAEU is access to flat-rate energy resources. Ibragimova (2015) argues that economic interdependence inside the EAEU has not sufficiently served economically weaker members as there is a debate in Bishkek about the requirement to share member countries' politically induced economic woes. Thus Kyrgyzstan seems to be less willing to shoulder responsibility for other members' economic weaknesses. Armenia has great expectations from the Union as Armenia's traditional security problems and complex regional surroundings make her to stand next to Russia. Armenia is seeking a short-term and tangible opportunity to improve the country's economy (Ibragimova, 2015).

According to Jan Strzelecki (2016), the expected direct economic benefits from integration will be limited, due to the differences in the member states' economic potentials. He argues that the impact of Russia's economy has been aggravated by the large economic disparities between the members of the EAEU (Russia's gross domestic product represents about $86 \%$ of the GDP of the entire EAEU; Kazakhstan represents less than 10\%, Belarus approximately 3.5\%, Armenia and Kyrgyzstan less than $1 \%$ together). In addition, trade relations within the EAEU are heavily dominated by exports from Russia. Strzelecki articulates the meaning of this by stating that the Union's members are largely dependent on the health of the Russian economy, and they consequently play a supporting role to Russia in the decision-making process (Strzelecki, 2016). Despite the EAEU's high level of integration, there seem to be two majör issues faced by the members. The first issue is that the members have an insufficient connection within the global economy together with a low level of industrialization. The second issue is that the EAEU is highly politicized and its structure is overly unbalanced as Russia is the largest and dominant member who can easily abduct the Union's policies (Ziguo, 2016).

\section{CONCLUSION}

In terms of the political commitment to the EAEU, Kazakhstan seems to be the most enthusiastic country among the members as the 
objectives and the goals of the EAEU have been identified in accordance with the President Nazarbayev's principles from the inauguration of the idea since 1994. He is not keen to put the brakes unless the EAEU transparently broadens the concept of the Union and goes beyond the economic realm. Kazakhstan does not embrace geopolitical ambitions as Nazarbayev stated many times that he wishes a functional economic union that is beneficial to the member states.

Asia has not been the most friendly or structured environment for integration methods of development. Its accommodation within the CIS has had different layers over the last two decades, especially with the involvement with Russia, which interplay of political relations and decisions are directly attached to sectors such as economic development, energy resources, and security enhancement. However, these relationships are not limitless. From the point of this study, the economic condition of the EAEU seems to depend primarily on the Russian economy. Thus Russia sees the Union as a mechanism for reinforcing Russian influence in the region, a barrier preventing the integration of the countries in this region with the West and an expression of the priority of Russia in the member countries. As a result of this understanding of the EAEU, Russia has been exploiting the other members' dependence on Russia. However, active-expensive foreign policy and the continuing crisis economic in Russia, stemming from the fall in oil prices on world markets and Western sanctions, the EAEU members seem to attempt to protect their own markets and remain reluctant to deepen their economic integration as they consider that Russian active-expensive foreign policy and economic crises may jeopardise the economic situation of the EAEU members. Although the experience of EAEU has so far demonstrated that many obstacles need to be overcome, this integration project has the potential not only promote economic growth but also cooperate with the international arena to overcome the economic-security integration issues of member countries.

This study has identified the EAEU as international economic integration as it brings the countries in the same geographical area. Taking into account its gross domestic product (2.2 trillion dollars), industrial production (1.3 trillion dollars), oil production (607.5 million tons $-1^{\text {st }}$ in the world) and gas production (682.6 million cubic meters- $2^{\text {nd }}$ in the world), the EAEU has a potential to be successful in the long term despite the fact that the economic structures, infrastructure facilities and geographical proximity are not similar and close. However, one of the most advantageous factors is that the members have political and cultural closeness which make the members better understand and communicate with each other. This study does not agree with the statements saying that there are two Eurasian Unions; one of them is the existing EAEU and the other one is the imaginary Eurasian Union fuelled by geopolitical a desire of Russian President Putin. It is argued that the idea of Eurasian Union is in action in the economic sphere as Nazarbayev has already repeated many times that the EAEU will stay as an economic union and will be a reliable bridge between Europe and rising Asia.

\section{REFERENCES}

Alexandrov, M. (1999). Uneasy Alliance: Relations Between Russia and Kazakhstan in the Post-Soviet Era, 1992-1997, Westport, Greenwood Publishing Group.

Aslund, A. (2016). Putin Gets It Wrong Again: Eurasian Economic Union Hurts Russia, Atlantic Council, available at http://www.atlanticcouncil.org/en/blogs/ne w-atlanticist/putin-gets-it-wrongagaineurasian-economic-union-hurts-russia

Astapenia, R. (2015). Belarus And The Declining Eurasian Economic Union, BelarusDigest, available at http://belarusdigest.com/story/belarus-anddeclining-eurasian-economic-union-23846

Balassa, B. (1961). Towards a Theory of Economic Integration, Kyklos, 14(1), 1-17.

BBC News. (2011). Russia sees union with Belarus and Kazakhstan by 2015, available at http://www.bbc.com/news/worldeurope-15790452

Blockmans, S., Kostanyan, H., \& Vorobiov, I. (2012). Towards a Eurasian Economic Union: The challenge of integration and unity, Centre for European Policy Studies, Ceps Special Report, No. 75, 1-32.

Borovikov, E., \& Danilov, I. (2014). Notes on the Future Court of the Eurasian Economic Union". Moscow Times, http://www.themoscowtimes.com/news/art icle/b2b-notes-on-the-future-court-of-theeurasian-economic-union/499094.html 
Çak, D., \& Çak, M. (2007). Gümrük Birliği'nin Getirdikleri ve Götürdükleri, İstanbul, İTO Yayınları.

Eurasian Economic Commission. (2016). About the Eurasian Economic Commission, available at http://www.eurasiancommission.org/en/Pag es/about.aspx

EEC. (2015). Volumes of mutual trade in 20102011, available at (http://www.tsouz.ru/db/stat/iCU201208/D ocuments/IALL201208_2.pdf).

Eurasian Economic Commission. (2015). Eurasian Economic Integration: facts and figures, available at http://www.eurasiancommission.org/en/Do cuments/broshura26_ENGL_2014.pdf

Eurasian Economic Commission. (2015). The EEC and the World Bank Have Agreed to Cooperate in the Field of Tax Policy of the Eurasian Economic Union Member States, available at http://www.eurasiancommission.org/en/na e/news/Pages/19-02-2016-1.aspx

Eurasian Economic Union. (2016). General Information, available http://www.eaeunion.org/?lang=en\#about

EurasiaNet. (2016). Is Kazakhstan Getting Eurasian Union Blues?, available at http://www.refworld.org/docid/5704c1ba4. html

Eurasian Economic Union Law Portal. (2014). Treaty on the Eurasian Economic Union, available at https://docs.eaeunion.org/enus/Pages/DisplayDocument.aspx?s=bef9c79 8-3978-42f3-9ef2d0fb3d53b75f\&w=632c7868-4ee2-4b21bc64-1995328e6ef3\&l=540294ae-c3c94511-9bf8-aaf5d6e0d169\&EntityID=3610

Galdini, F., \& Nematov, E. (2016). Kyrgyzstan: Putin's Eurasian Economic Union and Its Discontents, The Diplomat, available at http://thediplomat.com/2016/05/kyrgyzstan -putins-eurasian-economic-union-and-itsdiscontents/

Gazeta.ru. (2013). Suverenitet ne ikona' (Sovereignty is not an icon), available at http://www.gazeta.ru/business/2013/10/24/ 5722545

Güran, N., \& Aktürk, İ. (1997). Uluslararası İktisadi Kuruluşlar, İzmir, Anadolu Matbaacılı.
Ibragimova G. (2015). Does the Eurasian Economic Union Have a Future? Russia Direct, http://www.russiadirect.org/debates/does-eurasian-economicunion-have-future

İmanov, V. (2007). Rusya'nın Medeniyetsel Kimlik İnşası olarak Avrasyacılık, Basılmamış Doktora Tezi, Marmara Üniversitesi, İstanbul.

İncekara, A. (1995). Globalleşme ve Bölgeselleşme Sürecinde Nafta ve Etkileri, İstanbul, İstanbul Ticaret Odası Yayınları.

Kargül, M. (2010). Tehdit ve Fırsatlarıyla Dünya Ekonomisi, Ankara, Nobel Yayıncılık.

Kassenova, N. (2012). Kazakhstan and Eurasian Economic Integration: Quick Start, Mixed Results and Uncertain Future. Russia Nei Reports, No:14, 1-29.

LIBERTAS. (2016). Eurasian Economic Union Observer, Issue 1 / 2016 (1th quarter), available at http://www.libertasinstitut.com/wpcontent/uploads/2016/03/EurasianObserver 1_2016.pdf

Lagutina, M. (2013). Eurasian Economic Union: Issues of Global Regionalization, Eurasia Border Review, 5(1): 95-111.

MFA of the Republic of Belarus. (2015). Belarus' Presidency in the EAEU bodies in 2015, Eurasian Economic Union in brief, available at www.mfa.gov.by/upload/EAEU-engbroshura.doc

Ministry of Foreign Affairs of the Republic of Belarus. (2016). Eurasian Economic Union, available at http://mfa.gov.by/en/organizations/member ship/list/aa16658947a49c28.html

Mominkulov, C. (2012). Avrasya Birliği Fikrine Orta Asya'dan Tarihi Bir Bakış, available at http://www.orsam.org.tr/tr/yazigoster.aspx ?ID=3425

Mostafa, G. (2013). The concept of Eurasia: Kazakhstan's Eurasian policy and its implications, Journal of Eurasian Studies, 4 (2), 160-170.

Mostafa, G., \& Mahmood, M. (2013). The Customs Union Between Kazakhstan, Russia and Belarus: An Analysis, Otan Tarihi, 4(64), 25-33.

Nazarbayev, N. (2014). Factsheet: Kazakhstan and the Eurasian Economic Union, Embassy of the Republic of Kazakhstan in the Russian 
Federation, available at http://www.kazembassy.ru/en/mpolitika/67 63-2014-06-02-12-09-27

Nazarbayev, N. (1997). Asırların Kavşağında, Ankara, Bilig Yayınları.

Nazarbayev, N. (2011). Avrasya'nın entegrasyonunu savunuyorum, available at http://avrupa.hurriyet.com.tr/haberler/duny a/1037463/avrasyanin-entegrasyonunusavunuyorum

Nazarbayev, N. (2011). Evraziiskii Soyuz: ot idei $\mathrm{k}$ istorii budushego" (Eurasian Union: From Idea towards Future History, Izvestia (News), available at http://izvestia.ru/news/504908

- Nazarbayev, N. (2013). Kazakhstan Prezident Nursultan Nazarbaev Minskide Joğarı Evraziyalık Ekonomikalık Kenes Otırısına Katıstı (Kazkahstan President Nursultan Nazarbayev Participated in Eurasian Economic Union Meeting in Minsk), available at http://www.akorda.kz/kz/events/internatio nal_community/foreign_visits/page_215076

Özdal, H. (2015). Avrasya Ekonomik Birliği: Bir Medeniyet Projesi, available at http://www.abhaber.com/avrasyaekonomik-birligi-bir-medeniyet-projesi/

Popescu, N. (2014). Eurasian Union: the real, the imaginary and the likely, CHAILLOT PAPERS for European Union Institute for Security Studies, Paris. No (132), 1-48.

Putin, V. (2011). Novyi Intergrationnyi Proekt dlia Evrazii, buduse, kotoroe rojdeatsiya segodnaya (A new integration project for Eurasia - the future is born today), Izvestia, available at. http://izvestia.ru/news/502761

Putz, C. (2016). A ‘Blurry’ Union: Kyrgyzstan and the Eurasian Economic Union", The Diplomat, available at http://thediplomat.com/2016/02/a-blurryunion-kyrgyzstan-and-theeurasianeconomic-union/

Sabır, H. (2002), Gelişmekte Olan Ülkeler Arasında Ekonomik Entegrasyon: Mercosur Örneği, Dış Ticaret Müsteşarlığı Dergisi, 25(7), 95.

Sahakyan, A. (2016). Eurasian Economic Union is a Good Deal for Russia, but No One else, Kyiv post, available at http://www.kyivpost.com/article/opinion/o p-ed/armine-sahakyan-eurasian- economicunion-is-a-good-deal-for-russiabut-no-one-else-408756.html

Shebarova, N. (2005). "Razvitie Globalizazii cherez Liberalizatsiiu Regionalnykh Economicheskikh Sviazei (Development of Globalization through Liberalization of Regional Economic Connections), Vestnik MGTU 8(2), 348-354.

Sputnik. (2016). Israel, EEU will Reach Agreement on Free Trade Zone in Few Months, http://sputniknews.com/business/20160208 /1034413546/israel-eeufreetrade.html\#ixzz42yKRUIM3

Statistical Agency of the Republic of Kazakhstan. (2011). Kazakhstan za gody nezavisimosti 1991 - 2010 (Kazakhstan During the Years of Independence), Astana.

Strzelecki, J. (2016). The Eurasian Economic Union: A Time of Crisis, OSW Commentar, http://www.osw.waw.pl/en/publikacje/oswcommentary/2016-02-

01/eurasianeconomic-union-a-time-crisis

TASS. (2016). SCO and EAEU Countries to Announce Economic Continental Partnership Agreement available at http://tass.ru/en/economy/860102

TASS. (2015). Eurasian Economic Union Can Start Talks on Free Trade Zone with Egypt in 2016, available at http://tass.ru/en/economy/842227

TASS. (2015). China Backs Putin's Model of Eurasian Integration, available at http://tass.ru/en/economy/841551

TASS. (2015). Lavrov: Eurasian Economic Union has Potential for Expansion, available at http://tass.ru/en/politics/844625

TASS. (2016). Kazakhstan's Ruling Party Calls for Integration with EAEU, Stronger Ties with Russia", Astana, available at http://tass.ru/en/economy/852979

Vinokurov, E. (2012). The Customs Union and the Single Economic Space: Towards the Eurasian Economic Union, EDB Eurasian Integration Yearbook, Almaty.

Wisniewska, I. (2012). The Custom Union of Belarus, Kazakhstan and Russia: a way to strengthen Moscow's position in the region", ISPI Analysis, 146(1), 1-6.

Yıldız, M. (1999). Bütünleşme Biçimleri ve Avrupa Birliği, Dış Ticaret Müsteşarlığ 1 Dergisi, 15(4), 89. 
Yiğit, M. (2003). Ekonomik Entegrasyon, İstanbul, Beta Yayınevi.

Ziguo, L. (2016). Eurasian Economic Union:Achievements,Problems and Prospects, China International Studies, available at

http://www.ciis.org.cn/english/201608/19/content_8975486.htm

\section{ABOUT THE AUTHOR}

Serdar Yirmaz, email: serdaryilmaz@mu.edu.tr

Dr. Serdar Yilmaz is an Assistant Professor at the Department of Political Science and International Relations in Muğla Sitkı Koçman University Turkey. He has implemented several courses in international relations especially regarding Central Asia, Caucasia and Turkish Republics in Central Asia. He also imlemented a field research about Kazakhstan's Turkey Policy in Kazakhstan for five months in 2014 and worked as a guest researcher at the KIMEP University in Almaty. His research interests include: Globalisation, Foreign Policy Analysis, Domestic Structure and Foreign Policy of Turkish Republics in Central Asia and Caucasus, International Energy, International Organisations, Contemporary Central Asia: Domestic and Foreign Policy, Economy and Society. He has published several peer-reviewed articles and chapters in journals and books such as International Relations and Diplomacy, International Journal of Liberal Arts and Social Science, International Journal of Academic Value Studies, and Eurasian Politics and Society: Issues and Challenges. 